The Code Revision.-An Open Letter. Bostox, April 26, 1894.

To H. D. Holton, IT. D., Chairman of the Majority Committee of the Revision of the Code of Medical Ethics:

Dear Sir:-Perhaps I have been remiss in myduty, as also in privilege, in permitting so long a period to elapse before replying to your thoughtful letter. However, I have felt that I would prefer to examine your work as completed before writing, knowing that it is not too late for your Committee to accept modifications which meet their approval.

It is so much easier to play the rôle of critic, than to formulate, that I would in advance thank you for your earnest efforts in the behalf of the profession.

If you will note that section of my address of two years ago which prompted the appointment of your Committee, you will see that I view the mission and scope of the AMERican Medical Associatron from quite a different standpoint than that of the majority report of your Committee. First, that it should be a representative body of the whole profession, at present consisting of quite one hundred thousand in number, doubtless to be doubled in the next century. Each and every member of our profession should be so co-related to the Association, that he is an integral part of it, as for example, the voter in the most obscure town has the assurance that he is an active participant in the affairs of the commonwealth, with a no less just pride that he is a citizen of the general government, and may become a sharer in its highest honors and emoluments.

In the actuality of bodily presence, as a participant in the affairs of our great annual meetings, the number must be limited, and in the limitation of the number, it should be representative. This delegated power must necessarily mean something and that something must find its expression as a sharer in the governmental affairs of the AssociaTION. This is felt in the power to select their own officers and, under codified rules of action to govern their own affairs. The more important object, however, sought thereby should be clearly scientific improvement. To keep these dual objects equally in mind is not always easy. I have long felt that the possibilities of membership in the Association were sufficiently liberal. On the one hand, it should be considered an honor and a privilege worthy of attainment, while on the other, the restriction should not be so great as to exclude any earnest, ambitious professional man from becoming a member. In making active membership representative, this delegated authority from necessity acts for a more or less large constituency who are debarred the privileges of attendance and who shall be thus represented, your governmental rules must determine. Here lies your first fundamental difficulty, which I recognize as much as any member of your Committee.

Had we uniformity of State Examining Boards which would determine the status of a properly educated doctor, this work would be comparatively simple. A proper amount of scientific attainment would be our criterion. But hard as we all have labored to elevate the standard of medical education, I confess reluctantly to the feeling that, as yet we have not differentiated sufficiently to define readily the standard of our educated physician, and fear that, for the present at least, we shall have to fall back upon the unsatisfactory cognomen of the "regularly educated." Otherwise the political bias of the Examining Boards of the different States will give no end of practical difficulties, as instanced in your attempted answer to the query: "With whom may we properly consult?" States like Massachusetts which have no statutory limitations as to who may practice medicine, would fail entirely of qualification.

I have given my hearty approval to the efforts inaugurated under the leadership of Dr. Connor, of Detroit, for the im- provement of the Section work. In these subdivisions, it is easy to find place for the proper presentation of original research, and the thoughtful consideration of every contribution for the advance of the science and art of our profession, and these subdivisions must be the great corner-stones upon which to erect the temple of medical science. However, as viewed independently, they lack cohesion, and onr great National meetings, to reach a higher plane of success, must have something in common for all. To this end, fortunately our science blends in the discussions of public questions, upon which great masters are ever ready to consider it a high honor to address the entire assembly. For this reason it seems to me that beside the oration of the President, the annual addresses are of importance.

Will it not be well that we content ourselves in the present limitations ascribed to our Business Committee for the better scientific development of the Sectional work, and grant to the active members present that privilege, so dear to the American citizen, of exercising his delegated power in the choice of officers? This indeed may be stigmatized as political, nevertheless it enters into the very existence and makeup of the American boy before he differentiates into a doctor. Experience proves that no matter how select the committee, this quality does not depart from the members of the organization. Your Business Committee could hardly expect to be devoid of this attribute and with a certain show of justice might be criticised as "a close corporation, political ring, etc."

May we not, at least for the present, be content with your definition for the requirements of the graduate of medicine that he be carefully and thoroughly trained before he can be considered a general practitioner, and "that specialists must be this and something more?" Has not our Association long since recognized the special subdivisions of practice as "proper and legitimate" fields of labor, and that specialists shall be governed by the same rules of etiquette as has been laid down by general practitioners? Is not this quite sufficient?

There are many minor subjects upon which I can well understand there will be, and I think ought to be, differences of opinion. Under this head in our present Code comes a long chapter on the duties of patients to physicians. I am of ten asked in what does the obligation consist? Certainly the relation in many ways is a mutual one, and how can the physician give instruction, unless he is himself taught, or governed by certain rules of action!

As to the question of patenting of instruments, many justly claim hardship and loss by being denied this privilege, while others assert that the honor attached to the presentation of some new device should be ample compensation. If this be true, it is certainly aggravating, as has happened several times to me, that some other man with more effrontery than honesty, claims, and is accredited with the honor. In the patenting of medicines, the field where modern chemistry is doing so much for our profession, this question is still open to discussion. However, I can not help thinking that the subject of patents is such a prominent source of abuse and a covert means of swindling, that the individual better suffer personal loss than risk the injury that may accrue to the general public.

To me it has always been a matter of surprise that so much acrimony of feeling should be aroused in the discussion of codes and by-laws, but this pertains alike to all societies. Upon fundamental principles all should be agreed, in the matter of detail much latitude of action must be permitted. This is necessary when honest and able men disagree and will occur when designing men of doubtful honor would take advantage. When President of the Association I made an earnest effort to reconcile the differences between 
the great wings of the New York State medical profession. It seemed to me that the resolution which was unanimously adopted by the Association in 1885 as a conciliatory measure to meet the objections raised by the New York State Medical Society was ample:

"Resolved, That Clause 1, Article IV in the national Code of Ethics is not to be interpreted as excluding from professional fellowship on the ground of differences of doctrine or belief, those who in other respects are entitled to be members of the regular medical profession. Neither is there any article or clause in the said Code of Ethics that interferes with the exercise of the most perfect liberty of individual opinions or practice."

Reluctantly I was forced to believe that the time was not yet ripe for the harmonious adjustment of difficulties which pertained far less to the assumed faults of the Code, than to bitter dissensions on the part of individual members.

It was with this thought, without consultation with any, that I selected your honorable committee and imposed upon them the serious task of the consideration of the revision of the Code of Ethics. The gentlemen composing the committee were all known to me personally as men distinguished, not only for their learning and ability, but judging from their previous labors in the advancement of medical science, I deemed the Association peculiarly fortunate in being able to secure their services. It was a surprise to many that the first year of your efforts should be confined to a revision of the Constitution and By-laws, when you were appointed to consider only the revision of the Code of Ethics, doubtless, however, with the thought of securing an harmonic whole. To very many your revision seems extreme and I would suggest a marked modification somewhat as here outlined, preserving all there is of value in our really very excellent old Code, modifying only along the lines of advancing science, since if compelled to choose between the old and the new, as you have formulated it, I must support the former, an opinion which I can not doubt the large majority of our members will give approval.

HenRy O. Marcy.

\section{On Revision of the Code.}

New York, April 24, 1894.

To the Editor:-The venerable father of the Association in the issue of April 4, 1894, in his disapproval of the revision of the Code of Ethics asks the question: "In what direction this progress?-that of science and honor, or that of mammon and dishonor?" Now, as he has asked, it is discourteous not to reply. Also, this is the time for members to speak out their sentiments, as a matter of history and material for action. Dr. Davis says the Committee has emasculated the section on patents and proprietary medicines, making it prohibit only patents "for secret nostrums" (i.e., ours, from nos-we); " a medicine the ingredients of which are kept secret to restrict profits to proprietor or inventor."-Webster ; in other words, for "mammon and dishonor."

I have no doubt that the majority of the members have used antipyrin, phenacetin and sulfonal, out of which the German owners have reaped millions of dollars; yet they are practically secret nostrums patented, and I doubt if they can be made from the formulæ.

The ethics of these chemicals say that Associatron members can swallow their Code for Germans and not for Americans; this is free trade with a vengeance. There is a good deal of progress towards "mammon and dishonor" in the above use of such chemicals.

Further, the old Code shows the profession in a bad, if not dishonorable condition for themselves as book-makers. The father of the Association has copyrighted his books; i.e., his medical ideas in paper and ink; it is the same as a patent or proprietary nostrum (ours). Now, suppose he had produced ideas in hard rubber, metal, wood or even paper without ink; to patent such would be considered mammon and dishonorable, but protection for paper and ink is honor. In eternal common sense and fact, medical ideas, whether printed or not, are entitled to protection or no protection alike.

I know a medical man who got up medical ideas in hard and soft rubber, linen, iron and silk; these ideas he freely gave away to the profession; in England they were said to be the best for 6,000 years; English medical students could not graduate unless they knew about them. One day, when he thought he had thus done well he was much taken down by an American Medical Association member, one of the most eminent in the world in the line of such ideas, by the query : "Did you make any money by those ideas?" "No," was the reply. "You ought to have made $\$ 100,000$. Why did you not get them patented? How foolish !!!!" Not much honor, then, in giving the world those ideas, according to one of the very supporters of that Code that prohibited patents! Tell a member he shall not patent his ideas, and then blow him up because he did not and followed the Code! Is this honorable, consistent with truth, morality, the Ten Commandments, the Golden Rule? How does the Code of Ethics work as to nostrum (ours-proprietary) advertisements in the Journal? Take I- G-, advertised by the Journal, notwithstanding that the Connecticut State Agricultural Experiment Station after examination reported that it was common flour heated, bought at from $2 \frac{1}{2}$ cents to 5 cents and sold at $\$ 1$ per pound. Is it science to call common flour an extract made by chemistry when it is a powder chemically made? And the "greatest food for invalids?" Is this science and honor? And yet the old Code believers allow this, and the Association makes money publishing untruths.

If a member should advertise a proprietary medicine in the Journal or elsewhere, he would be subject to discipline. An outsider has greater privileges. I approve of the Committee's report as to this section also because it is a dead letter. Members are getting patents in spite of the Code, as they get copyrights. There is often more science in instruments than in books. The instrument represents new ideas; medical books are too often made by threshing out old straw and somebody's ideas because they sell best.

Another consideration: The late Dr. Louis Elsberg, a member, invented after years of study an admirable forceps for topical applications to the larynx, throat, posterior nares and nares. It took much study and time to get the right angle, 120 degrees, for the bend. It went on the market unprotected. The makers, who generally think they know more than the inventor (try it, if you do not think so), changed the angle variously - so that the forceps were a failure; I well remember how badly Dr. Elsberg felt when he knew that his instrument did not do the good it was capable of and thus relieve suffering, simply because he did not protect it from changes. I have known of like cases with other medical men; one gentleman of great eminence in his specialty in surgery has the pleasure of knowing the Government has ordered thousands of dollars worth of his instruments on which he has no protection, and hence no profit. Would it not have been better for this man, as well as others, to have made some money out of his brain children and thus conserved energy and perhaps brought forth more ideas of value? So long as our present system of economics is based on every man inheriting or earning money for his support, so long should his property be protected. We seem to forget that the competition will break down unjust monopolies and that only valuable things will stand. The greatness of our country has been made possible by inventions; the science of medicine would be nowhere but for patented inventions in locomotion, manufactures 